Revista

A Cor das Letras

\title{
A simbologia do animal na construção da personagem: o real e o irreal no conto Tigrela de Lygia Fagundes Telles
}

\author{
The animal symbology in character construction: the real and unreal \\ in Tigrela short story by Lygia Fagundes Teles
}

\author{
Antonia Marly Moura da Silva* \\ Universidade do Estado do Rio Grande do Norte, \\ Mossoró, Rio Grande do Norte, Brasil
}

\begin{abstract}
Resumo:No discurso mimético de Lygia Fagundes Telles, eventos aparentemente verossímeis cedem lugar à imaginação, imprimindo uma atmosfera de confronto entre o estranho e o familiar, o real e o irreal. No conto "Tigrela", integrante da obra Mistérios (1981), a personagem feminina é delineada com traços que confundem sua identidade. Trata-se da história de Romana e seu animal de estimação, Tigrela, uma fêmea de tigre com quem a mulher partilha o luxo e o conforto de um apartamento, adaptado para tal convivência. $\mathrm{Na}$ trama, a mulher ora vela ora revela seus traços animalescos ao mesmo tempo em que acentua atributos humanos na representação do animal. A caracterização dessa relação binária constitui terreno fértil para uma reflexão sobre os limites entre homem e bicho. Sob tal enfoque, faremos uma leitura da narrativa à luz dos conceitos de fantástico formulados por Roger Bozzetto (2001), IrèneBessière (2005), David Roas (2001, 2011, 2014), Julio Cortázar (1993), dentre outras referências da Teoria da Literatura.
\end{abstract}

Palavras-chave: Conto brasileiro. Lygia Fagundes Telles. Fantástico.

\begin{abstract}
In mimetic discourse by LygiaFagundesTelles, apparently credible events are assumed as imagination, providing a confrontation atmosphere between the strange and the familiar. In her "Tigrela" short story, part of her Mysteries work (1981), the feminine character description is identified by animal aspects that integrate her identity. The story of Romana and her pet, Tigrela - a female tiger with whom the woman shares her wealth and comfort in her apartment, fitted for that convenience. In a spectacular game, the narrator reveals and hides feminine savagery, at the same time he highlights human attributes in his animal representation. The unusual configuration in this binary relation constitutes a fertile soil for a reflection the limits between the human and unhuman, natural and supernatural. According to this approach, we have read this narrative based on fantastic concepts developed by Roger Bozzetto (2001), IréneBessière (2005), David Roas (2001, 2011, 2014), Julio Cotázar (1993) among other literature theory references.
\end{abstract}

Keywords: Brazilian short story. LygiaFagundesTelles. Fantastic.

\footnotetext{
* Professora da Universidade do Estado do Rio Grande do Norte, Mossoró, Rio Grande do Norte, Brasil. E-mail: marlymouras@uol.com.br.
} 


\section{INTRODUÇÃO ${ }^{1}$}

As narrativas populares, os contos maravilhosos e as fábulas de Esopo e de La Fontaine inauguraram, na tradição da ficção narrativa, a temática da animalização do homem ou a humanização do animal, acentuando valores e comportamentos humanos, bem como dramas protagonizados por criaturas enigmáticas que povoam o imaginário de todos os tempos. Não é necessário, entretanto, ir tão longe no tempo para levantar formas literárias que tornaram célebres a fusão entre homem e bicho. Na literatura moderna, alegórica ou metaforicamente, é abundante a ação de animais em situações atípicas, desencadeando sentimentos de empatia, de espanto e de medo. A incursão poética na dualidade humano/inumano, portanto, parece querer eliminar as fronteiras que separam racionalidade e irracionalidade.

$\mathrm{Na}$ literatura fantástica, formas milenares de zoomorfismo e antropomorfismo são objetos de reflexões uma vez que trazem à tona questões polêmicas como alteridade, integração natural ou experiência civilizada, linhas de força na ação dos seres ficcionais que operam na oscilação entre o crível e o não crível. Sua incidência no discurso romanesco presentifica aspectos da natureza do sobrenatural e do extraordinário, bem como fenômenos não habituais, inesperados, estranhos e, muitas vezes, inexplicáveis. Nas relações entre homens e animais, o caráter subversor da realidade instala-se em instâncias narrativas, suscitando questionamentos sobre o contrato mimético.

Nesta linhagem, é mérito das obras de Lygia Fagundes Telles a confluência real e irreal, uma vez que eventos anormais ou impossíveis encontram-se interligados aos fatos banais do cotidiano, geralmente, sem que ocorra qualquer sentimento de inquietação da parte dos seres ficcionais em relação aos eventos insólitos. Caricaturizados, os personagens são delineados com traços que confundem a identidade das espécies, desafiando o leitor a tentar reconhecer o entrelugar entre humanidade e animalidade.

$\mathrm{Na}$ ficção de Lygia Fagundes Telles, a caracterização dessa relação binária constitui terreno fértil para uma reflexão sobre a radical separação entre homem e bicho, dentre as quais convém lembrar o gato Rahul, um dos narradores do romance As horas nuas (1989), os ratos protagonistas do Seminário dos ratos (1977), o cachorro do conto "O crachá nos dentes" da obra A noite escura e mais eu (1995), dentre outros animais que povoam o discurso romanesco lygiano. Em Mistérios (1981), o conto "Tigrela", objeto de estudo neste trabalho, é outro exemplo dessa predileção temática. Trata-se da história de Romana e seu animal de estimação, Tigrela, uma fêmea de tigre com quem a mulher partilha o luxo e o conforto de um apartamento, adaptado para tal convivência. Na trama, Romana ora vela ora revela seus traços animalescos ao mesmo tempo em que acentua a humanização, a vaidade e uma série de preferências tipicamente femininas na figurativização do animal. No desenho fabular, a animalização de Romana e a humanização de Tigrela conferem ao relato um modo peculiar de transgressão da realidade ligada a interioridade humana, traço do fantástico contemporâneo, conforme ressalta Calvino (2011), escritor italiano que

${ }^{1}$ Este trabalho constitui um recorte dos resultados da pesquisa de Pós-doutoramento, intitulada $A$ arte da estranheza inexplicável: um estudo do conto fantástico no Brasil e em Portugal, desenvolvida em 2016, na Faculdade de Letras da Universidade de Coimbra, Portugal, sob a supervisão da Profa. Dra. Maria João Albuquerque Figueiredo Simões. 
teceu valiosas contribuições conceituais sobre a natureza do fantástico no prefácio à obra Contos fantásticos do século XIX: O fantástico visionário e o fantástico cotidiano.

Frente a isso, podemos dizer que no conto lygiano a dualidade das personagens mulher e bicho - realça um mundo alternativo de fantasia que parece circunscrever o sobrenatural numa lógica que aproxima o conto do sonho e da loucura para subverter as normas de funcionamento da realidade, o que nos leva a conceber tal elemento ligado à perturbações psíquicas.

Nesta perspectiva, nosso propósito neste trabalho é desenvolver uma leitura crítica do conto "Tigrela", destacando aspectos fantásticos na arquitetura da narrativa. Com tal direcionamento, pretendemos neste trabalho analisar o referido conto à luz dos conceitos de fantástico formulados por IrèneBessière (2005), Jacques Finné (1980), Italo Calvino (2011), David Roas (2001, 2011, 2014), Julio Cortázar (1993) dentre outras referências da Teoria da Literatura.

\section{DO FANTÁSTICO}

A querela em torno das fronteiras e da natureza da narrativa fantástica dificulta um consenso sobre esse modo ficcional. A hesitação ou a dúvida dos seres ficcionais em relação ao evento sobrenatural, a transgressão da realidade ou a subversão da lógica racional são expressões que a crítica repete para destacar determinantes da literatura fantástica. No debate corrente, a transgressão da concepção aristotélica de realidade e a representação de fenômenos impossíveis ou sobrenaturais são apontados como traços determinantes de tal forma romanesca. Neste debate, consideramos oportuno repetir que o fantástico se aloja no entrecruzamento de realidades, quando o natural e o sobrenatural se misturam sem criar qualquer tensão entre tais instâncias. Em outras palavras: o acontecimento insólito é o elemento desagregador da realidade ordinária, o responsável pela quebra das leis que regem o mundo real. Castex (1951 apud MAGALHÃES JÚNIOR, 1972, p. 66) afirma que o fantástico se caracteriza

por uma intrusão brutal do mistério dentro dos quadros da vida real, e este geralmente ligado aos estados mórbidos da consciência, que nos fenômenos de pesadelo ou delírio, projeta diante dela própria as imagens de seus terrores e de suas angústias.

Em suma, o fantástico ocorre quando um fenômeno de outra dimensão surge em um mundo semelhante ao nosso, esse fenômeno é o que configura o estatuto do sobrenatural, "aquilo que transgride as leis que regem o mundo real e não pode ser explicado porque não existe segundo essas leis (ROAS, 2014, p. 25).

De um modo geral, a ocorrência do sobrenatural no discurso mimético é notadamente apontada como marca distintiva do modo fantástico, sem a qual não ocorre a transgressão da realidade. Furtado (1980) afirma que a temática de índole sobrenatural é indispensável. Roas (2014) defende que o fantástico não pode sobreviver sem o sobrenatural. Tais observações revelam, no entanto, que o território do fantástico não se delimita facilmente, uma vez que outras formas literárias como o maravilhoso, o gótico, o horror, o realismo mágico, dentre outros discursos ficcionais, acomodam o sobrenatural 
como traço inspirador, realçando sua dinastia no discurso fabular. Assim, na defesa daquilo que poderia delimitar fronteiras com outros relatos, Roas (2014) ressalta que o sobrenatural não é o único elemento para mensurar a "fantasticidade", ou seja, o sobrenatural por si só não define a especificidade do fantástico em relação aos demais relatos não realistas. Nessa perspectiva, o discurso romanesco deve levar em conta a existência de duas realidades, a normal e a anormal, a ordinária e a extraordinária, pois, conforme Roas (2011, p. 48)

para que el efecto fantástico se produzca, el mundo construido en el interior del texto siempre ofrece signos que puedan ser interpretados a partir de la experiencia del mundo que tiene el lector. Eso le permite contrastar las opuestas naturalezas de los acontecimientos narrados y captar su relación conflictiva.

É, pois, importante considerar uma aliança entre o real e o sobrenatural, uma vez que o real é concebido como fundamental para a composição da atmosfera fantástica. Para tanto, é significativo tomar como referência o fato de que a realidade é construída histórica e culturalmente, e, sobretudo, que o fantástico evolui, tal como a literatura e a sociedade, pois conforme Jacques Finné (1980, p. 14) [c]omme tout genre littéraire, le fantastique n'est pas statique. Il a évolué, aucours de as brève existence, à tel point qu'il mériterait non une thèse, mais une série de thèses".

É própria da narrativa fantástica a expressão de um cenário realista que assegure a confluência de realidades - a verossímil e a inverossímil. Em síntese: enquanto o realismo firma um contrato mimético com a realidade, o fantástico transgride essa realidade, pois, não tem compromisso com a verdade. Porém, para que o insólito se aloje, o relato deve ser crível. O que nos faz lembrar a posição oportuna de Ítalo Calvino (2011, p.3-4):

O fantástico diz coisas que se referem diretamente a nós, embora estejamos menos dispostos do que os leitores do século passado a nos deixarmos surpreender por aparições fantasmagorias, ou melhor, estamos prontos a apreciá-las de outro modo, como elementos da cor da época.

É importante destacar que a sociedade moderna, regida pela ciência e pela razão criou novos monstros, muitas vezes comandados por perturbações psíquicas como o sonho e a loucura, como já foi dito aqui. Daí observarmos em relatos fantásticos modernos a supremacia de problemáticas relacionadas à condição humana ou temas antropocêntricos, como ressalta Rodrigues, (1988) ao referir-se ao modo fantástico da atualidade. Nesta linhagem, a poesia e o imaginário atuam como objetos de uma assimilação simbólica, inscrevendo o desenho ontológico que a literatura fantástica contemporânea perscruta. Sob tal perspectiva, faremos uma leitura do conto de Lygia Fagundes Telles, procurando compreender a transgressão da realidade que o fantástico opera na retomada do tema clássico da fusão entre homem e animal. 


\section{A REPRESENTAÇÃO INSÓLITA DE BICHOS-HOMENS E VICE-VERSA}

$\mathrm{Na}$ tradição do medo, contadores de histórias e escritores investiram em diferentes recursos imagéticos para seduzir e encantar seu público. Na literatura fantástica, por sua vez, escritores acentuaram o estreitamento entre realidade e ficção para arrebatar as emoções do leitor e ampliar o efeito catártico do discurso romanesco. Assim, seres sobrenaturais oriundos do mito e do imaginário, concebidos em tradições e crenças como agentes da desordem e ameaças de vida, serviram para reforçar mistérios humanos e enaltecer o desconhecimento do mundo e os perigos daí decorrentes.

Convém destacar, no entanto, que o medo é um atributo cultural que evolui de acordo com a sociedade. Nesta perspectiva, no mundo moderno, comandado pela racionalidade e pela ciência, o modo de operar o sobrenatural, traço instigador da transgressão da realidade, também sofre mudanças em decorrência das transformações sociais. Desse modo, monstros, bruxas, ogros, fantasmas e vampiros - figuras que consagraram a literatura não realista, comumente associados como agentes do sobrenatural, parecem não funcionar mais como referências instigadoras dos temores modernos, o que nos motiva a identificar traços distintivos do modo fantástico de ontem em relação ao fantástico contemporâneo. Segundo Calvino (2011, p. 13):

[...] o verdadeiro tema do conto fantástico oitocentista é a realidade daquilo que se vê: acreditar ou não acreditar nas aparições fantasmagóricas, perceber por trás da aparência cotidiana um outro mundo, encantado ou infernal. É como se o conto fantástico, mais que qualquer outro gênero narrativo, pretendesse "dar a ver", concretizando-se numa sequência de imagens e confiando sua força de comunicação ao poder de suscitar "figuras". [...] O elemento "espetaculoso" é essencial à narração fantástica, por isso é natural que o cinema se tenha nutrido tanto dela. Mas não podemos generalizar. Se na maior parte dos casos a imaginação romântica cria em torno de si um espaço povoado de aparições visionárias, há também o conto fantástico em que o sobrenatural permanece invisível, é mais "sentido" do que "visto", participando de uma dimensão interior, como estado de ânimo ou como conjectura.

Nesta perspectiva, é importante considerar os contornos assumidos pelo fantástico na atualidade, predominantemente voltado para problemáticas em torno do eu, ou da “dimensão interior", conforme declara Calvino (2011). É lícito tomar como referência a evolução da sociedade e da literatura, bem como o diálogo entre ficção e realidade. Desse modo, não há como ignorar os fundamentos científicos e racionais que definem formas de pensamento e de conhecimento que focalizam a condição humana e também a natureza e a cultura.

A sociedade moderna, marcada por transformações que interferem diretamente no modo de vida e na relação entre os indivíduos, de um modo geral, é concebida como a era do tempo medido e calculado, o berço da informação e do consumo, do avanço digital, da ciência e da tecnologia e da produção de artefatos industrializados sofisticados. Este é, também, o cenário do crescimento da cidade, da explosão demográfica e de outras transformações que desvencilharam o ser humano de todas as formas tradicionais de ordem social, transformações essas que, conforme Giddens (1991, p. 10-11) "vieram a 
alterar algumas das mais íntimas e pessoais características de nossa existência cotidiana”. Estratificada, caótica e conturbada, a sociedade moderna é signo da segregação, da miséria e de outras contradições que interferem diretamente nas relações humanas, no comportamento e nas formas de interação social. É o palco da luta pela sobrevivência e de outras situações extremas que põem em cheque condutas morais do indivíduo.

Neste cenário, a violência adquire um estatuto de normalidade. No espetáculo da vida, o ser humano é um ator em cena na luta pela sobrevivência. Assim, em clima de combate permanente, consciente ou inconscientemente, o homem parece perder suas referências humanas e ser submetido às leis da natureza, da selvageria e da brutalidade. Em outras palavras, o homem, vítima das leis da selva, é animalizado pela sociedade.

No compasso dessa realidade, mudanças de comportamento acentuam a individualização do sujeito citadino, isolado em apartamentos, vítima de relações sociais transitórias e superficiais, determinadas por ocasiões. Em decorrência disso, o indivíduo moderno coloca-se cada vez mais na condição de refém da interação virtual, uma cultura que parece acentuar o afastamento do contato físico. Em síntese, na sociedade da "fragilidade dos laços humanos", como assinala Bauman (2004), o ser humano trava a ardilosa batalha contra a solidão e, por isso, como um herói em batalha, se lança nas mais variadas formas de "paranóias" moderna na relação com o outro. Sob o estigma do isolamento social, busca o contato virtual através de redes sociais - eliminando fronteiras geográficas - ou a convivência civilizada com animais - uma forma de interação que permite também a prerrogativa do tato.

Esta é a sociedade que parece querer desconstruir a radical separação entre homem e bicho, entre humanidade e animalidade. $\mathrm{Na}$ inversão de papéis e de valores intensificase a atitude da domesticação dos bichos. Comportamentos desordenados revelam novos contratos de convivência e total integração entre as espécies, criando situações atípicas sobre a dualidade cultura/natureza. Cada vez mais próximos do convívio humano, os animais - treinados e mimados como gente - habitam espaços domésticos, usam roupas de grife, frequentam salões de beleza próprios, dentre outras experiências inusitadas que denotam a projeção de atitudes e sentimentos humanos na domesticação dos bichos e possíveis tentativas de eliminar o sectarismo entre humano e inumano.

Em sintonia com tal realidade, figurações de animais evocam formas seculares de zoomorfização ou, por outro viés, formas de antropomorfismo, atributos retomados metaforicamente para problematizar questões prementes e atuais na literatura e na sociedade. Neste universo, não há como não lembrar animais célebres que figuram em narrativas de ficção como o gato de "O gato preto" de Edgar Allan Poe, o cachorro Quincas Borba do romance de mesmo nome de Machado de Assis, o coelho Teleco, do conto "Teleco, o coelhinho" de Murilo Rubião, o homem onça do conto "Meu tio, o Iauaretê" de João Guimarães Rosa, dentre outros exemplos. Assim, defendemos a hipótese de que a metáfora do animal ocupa espaço privilegiado em poéticas modernas, realçando a dualidade humano e inumano num só corpo ou a fusão entre selvageria e civilização.

Nesta linhagem, retomando o tema clássico do entrelaçamento de tais instâncias, Lygia Fagundes Telles demonstra certa predileção por tal problemática ao enaltecer a 
congruência do real e do irreal, sem qualquer explicação sobre a estranheza da situação. A representação da relação entre bicho e ser humano no conto "Tigrela", integrante da obra Mistérios (1981), permite a identificação imediata de uma certa inspiração na tradição oral e mais especificamente no modo de fabulação do mito arcaico, o que pode ser observado na caracterização da figura central da narrativa, Romana, ou na imagem da fêmea de tigre, Tigrela, com quem a personagem convive.

Sob tal enfoque, faremos uma leitura do conto procurando reconhecer o lugar ocupado pelos recursos do duplo e do fantástico, atentando para as tensões que são do campo do imaginário, do fantasioso, conforme demonstraremos no fragmento que segue.

\section{O DUPLO DA PERSONAGEM: TIGRELA E ROMANA ORIGINAL OU CÓPIA?}

Romancista e contista, Lygia Fagundes Telles ${ }^{2}$, com seus noventa e três anos de idade, é notadamente reconhecida pela crítica por sua literatura intimista e marcadamente fantástica. Considerada um dos nomes representativos da ficção pós-moderna, a escritora é a primeira mulher brasileira a ser indicada ao prêmio Nobel de Literatura (2016). A publicação de sua obra em diversos países, a adaptação para TV, teatro e cinema, os vários prêmios conquistados, dentre eles o Prêmio Camões (2005), e a intensa e vasta fortuna crítica são alguns dos indicadores que confirmam sua aceitação pelo público leitor e, sobretudo, a consagração de seu nome no cenário das letras nacionais e internacionais. Sua fecunda trajetória no universo da poesia e a revisão permanente da produção literária revelam o labor e a dedicação da autora de Mistérios ao ofício de escrever.

A técnica e engenhosidade com que representa a sondagem interior e os desencontros vividos por seus personagens, bem como o modo com que delineia uma visão particular da realidade e da supra realidade são traços que pontuam sua linhagem estética, sobretudo, a originalidade e a universalidade de sua arte literária. Nesta filiação, outros aspectos se agregam ao discurso romanesco lygiano, como, por exemplo, o entrecruzamento do mito e da poesia, do sonho e da realidade, um mergulho no desconhecido e no imaginário, traços que delimitam fronteiras com a herança realista predominante na literatura.

Assim, no universo da realidade e da fantasia verifica-se a expressividade do tema do duplo como manifestação do fantástico, marca promissora na ficção de Lygia Fagundes Telles. Em sua narrativa, marcada por um distanciamento dos discursos mais racionalistas, o mistério é elemento catalisador de domínios poéticos que se aproximam do absurdo. No próprio testemunho da escritora ao referir-se ao seu fazer poético, o interesse pelo "indefinível” é a sua marca: "Na infância, um mistério me puxou pela manga. Desde então o indefinível sempre me atraiu". (TELLES, 2004, apud RIBEIRO, 2008, p. 12)

\footnotetext{
2 Embora tendo iniciado em 1938 com o livro de contos Porão e Sobrado, 1944 é considerado o ano de sua estréia oficial com a publicação da coletânea de dez contos intitulada Praia Viva. Mas, conforme Antonio Candido (2000), é o romance Ciranda de pedra(1954) o indicador de sua maturidade intelectual.
} 
De um modo geral, na ficção da autora de Telles o fantástico ocupa lugar de destaque, vertente ficcional notadamente apontada pela crítica como marca de sua narrativa. Aqui é oportuno destacar o trabalho de Vera Maria T. Silva (2001), já referida neste texto, que fez um levantamento criterioso de aspectos da metamorfose em contos da autora. Outro estudo digno de menção é o de Berenice Sicas Lamas (2004) que situa o duplo em sete contos, à luz do imaginário de Gilbert Durand. Nos contos da escritora há uma preferência por "temas corriqueiros de história simples, abarcando também situações complexas e estranhas, até desembocar no sobrenatural e no fantástico, rompendo com os limites racionais do humano" (LAMAS, 2002, p. 112). A escritora "constrói enredos em que o natural se entrelaça ao sobrenatural", conforme afirma Lucas (1983, p. 134).

O autor acrescenta:

É comum na sua ficção que o sobrenatural se misture à ordem secular das coisas, como se não houvesse distância entre o real e o surreal. Fantasias secretas, noturnas e diurnas, encontram expansão no seu texto, enfatizando ora a vida, ora a morte. [...] O racional se entrelaça com a rotação do insólito, do maravilhoso e das propriedades mágicas. A lógica do real se apresenta em estado de transe. (LUCAS, 1999, p. 15 apud RIBEIRO, 2008, p. 40).

Assim, seguindo tal linha de pensamento, no estudo pretendido centramos nossa atenção na dualidade humano e inumano, entendendo que na obra de Lygia Fagundes Telles o modo fantástico suscita reflexões sobre questões inquietantes e inexplicáveis da realidade. De modo particular, instâncias como humanização e animalidade estão estritamente ligadas aos fatos banais do cotidiano. No discurso romanesco lygiano, tais problemáticas se manifestam na dicotomia eu/outro, em metáforas como a sombra, o espelho, a máscara, etc, ou na representação de forças antagônicas como Eros e Tânatos, o bem e o mal, deus e o diabo, sombra e luz, dentre outros. Geralmente, esses atributos são utilizados para problematizar o natural e o sobrenatural, o real e o supra-real, num tratamento mimético de acentuada valoração aos aspectos simbólicos e míticos que se inserem na esfera do imaginário.

Convém lembrar que o duplo, na visão oportuna de Bravo (1998, p. 263), baseada nos estudos de Keppler:

é ao mesmo tempo idêntico ao original e diferente - até mesmo o oposto - dele. É sempre uma figura fascinante para aquele que ele duplica, em virtude do paradoxo que representa (ele é ao mesmo tempo interior e exterior, está aqui e lá, é oposto ecomplementar), e provoca no original reações emocionais extremas (atração/repulsa).

À luz deste pensamento, é perceptível a natureza dual e paradoxal do conceito, que comporta um jogo antagônico entre categorias como "idêntico e diferente", "interior e exterior", "aqui e lá”, “oposto e complementar", "atração e repulsa”. Dessa forma, é possível dizer que o duplo configura-se a partir de um paradoxo, pois a confluência e a cisão entre o original e a cópia ou mesmo a natureza do semelhante/dessemelhante originam a indecidibilidade que se aloja em torno da problemática da dualidade.

Sob tal enfoque, na própria natureza do duplo se aloja um caráter ambíguo e ambivalente, pois tal atributo comporta uma dialética indissolúvel como os pólos eu e 
outro, eu e não-eu, o mesmo e um, questões prementes que são do âmbito da identidade e da alteridade, da identidade e da diferença. Conforme estabelece o conceito referido, há uma indecidibilidade no estatuto do duplo que é, ao mesmo tempo, oposto e complemento, aqui e lá, dentre outros termos que evocam uma contradição ou a fusão de elementos e de realidades.

$\mathrm{Na}$ ficção lygiana, a figuração de opostos - eu e outro, vida e morte, sagrado e profano, por exemplo -e a atmosfera surreal predominam no discurso ficcional, provocando uma ambigüidade necessária para a eficácia da atmosfera insólita, o que nos faz lembrar da oportuna declaração do escritor e ensaista José Paulo Paes (1998, p. 82) sobre os traços do fantástico lygiano:

\begin{abstract}
Na vertente fantástica da obra de ficção de Lygia Fagundes Telles, o desencontro, amiúde registrado pelo sismógrafo da premonição, entre o natural e o sobrenatural, o verossímil e o inverossímil, abre uma freta metafísica que a sutileza de arte desdenha alargar. Mesmo porque, por essa fresta, só se pode olhar com os olhos da imaginação, e a olhos que tais sabem-no bem os poetas e o ficcionistas-poetas como Lygia Fagundes Telles - interessa menos ver aquilo que se mostra do que aquilo que reluta em mostrar-se.
\end{abstract}

Em "Tigrela", publicado inicialmente na obra Seminário dos Ratos (1977), o nono conto da obra Mistérios ${ }^{3}$ (1981), o tema do duplo é ponto focal na arquitetura da narrativa. Ao mesmo tempo em que realça um confronto de realidades - a ordinária e a extraordinária - a história sugere, metaforicamente, a cisão da figura feminina ou facetas da identidade e da alteridade em que afloram aspectos de ordem psíquica determinantes das relações entre humano e inumano, o eu e o outro, o eu e o não-eu. No conto, a incursão na temática do duplo se inscreve na representação dos personagens centrais, Romana e Tigrela, na medida em que é realce na ação os pólos civilidade e selvageria, dentre outros campos ambivalentes. Trata-se da história de Romana e seu animal de estimação, Tigrela, uma fêmea de tigre com quem a mulher partilha o luxo e o conforto de um apartamento, rodeado de jardim, "uma selva em miniatura" (TELLES, 1981, p. 98), adaptado para tal convivência. Na trama, Romana ora vela ora revela seus traços animalescos ao mesmo tempo em que acentua vaidades e preferências tipicamente femininas na figurativização do animal.

É importante ressaltar que a caracterização dessa relação binária é constituída a partir de um foco narrativo dual: ora em terceira pessoa, do ponto de vista de uma amiga de Romana, não nomeada, referida apenas uma vez como "minha querida", ora em primeira pessoa, na voz de Romana - que vai delineando a integração de Tigrela no cotidiano doméstico, bem como a experiência civilizada do animal.

A dualidade é referida textualmente pelo narrador ao inscrever a imitação como signo para mapear fronteiras e comportamentos das espécies ou a fusão entre mulher e bicho.

\footnotetext{
3 A edição brasileira da obra Mistérios é de 1981, porém a coletânea foi publicada inicialmente na Alemanha com o título Contos fantásticos, como resultado de um projeto dos professores Maria Luiza e Alfred Opitz, conforme Nota da editora Nova Fronteira, nas primeiras páginas da obra.
} 
Dois terço de tigre e um terço de mulher, foi se humanizando e agora. No começo me imitava tanto, era divertido, comecei também a imitá-la e acabamos nos embrulhando de tal jeito que já não sei se foi com ela que aprendi a me olhar no espelho com olho de fenda. Ou se foi comigo que aprendeu a se esticar no chão e deitar a cabeça no braço para ouvir música, é tão harmoniosa (TELLES, 1981, p. 93).

No campo semântico da mencionada imitação, atribui-se, por oposição, a polaridadede sentido original versus cópia, controvérsia que comporta outras associações como identidade e alteridade, identificação e reflexo, suscitando questionamentos sobre o princípio da identidade. Sob a ótica de Heidegger (1991, p. 139),

[o] princípio da identidade soa, conforme uma fórmula coerente: $\mathrm{A}=\mathrm{A}$. [...] A fórmula $\mathrm{A}=$ A fala de uma igualdade. Ela não nomeia A como o mesmo. A fórmula corrente para o princípio da identidade encobre, por conseguinte, justamente o que o princípio quereria dizer: A é A, quer dizer, cada A é ele mesmo.

No âmbito das noções de igualdade e de identidade, oportuno é o modo de configuração de tal atributo no comportamento de Tigrela, pois, conforme se verifica no discurso do narrador, na ação do animal parece haver um desejo de se constituir "igual" a outro: "No fim quis se atirar do parapeito do terraço, que nem gente, igual. Igual, repetiu Romana procurando o relógio do meu pulso" (TELLES, 1981, p. 94). Acrescente-se, ainda, que a menção ao ato de imitar denota aproximações com outros campos correlatos, tais como: representação, simulacro, máscara, sombra, disfarce, em síntese a metáfora do sujeito dividido, um drama centrado no reflexo ou na cegueira narcísica vivida pela mulher que parece conceber seu animal de estimação como um objeto de desejo, ser representativo de uma identificação. Dessa forma, podemos supor que Tigrela configura o duplo de Romana e vice-versa, um jogo de reflexos que enaltece elementos como a semelhança, o contraste e a complementaridade entre os seres.

No exercício contínuo da domesticação, Romana projeta um comportamento para o animal que adquire a esfera de um desejo pessoal: tornar a tigresa igual ao humano. Através da posse simbólica de uma imagem idealizada, a mulher assume o desafio de transformar o animal, de torná-lo igual a outro de sua espécie ou a si mesma. Neste jogo especular, parece haver um desejo de completude, pois, Tigrela representa o outro que falta a Romana, o que parece configurar o vazio da separação.

$\mathrm{Na}$ mitologia grega, o mito de Narciso é a referência clássica sobre a natureza da dualidade do eu, pois emblematiza, a partir do jogo especular com o espelho, um vazio, decorrente disso, aflorando um amor unilateral ou o exagero por si mesmo. Assim, como base na apropriação metafórica do referido mito, podemos dizer que Romana é um Narciso moderno que projeta em seu animal de estimação uma possibilidade de completude. Tigrela representa, assim, o inacessível, aquilo que denota uma falta, um objeto de desejo. A supervalorização das vontades da tigreza constitui a possibilidade de preenchimento do vazio narcísico, o não-eu. Em suma, o animal parece representar aquilo que a mulher não possui.

Ao referir-se aos moldes do amor narcísico Kristeva (1988, p. 64) afirma: "Narciso mítico debruçava-se no fim das contas heroicamente sobre esse vazio, em busca do 
elemento aquático materno, possibilidade de representação de si ou de um outro: de alguém para amar".

Segundo Rosset (2008, p. 108): “O narcisista sofre por não se amar: ele só ama a sua representação. [...] Este é o miserável segredo de Narciso: uma atenção exagerada ao outro. (Grifos do autor). O que se verifica na ação de Romana, o desapego de si e a paixão pelo outro reconhecido, simbolicamente, em Tigrela.

Sem pretensões de esmiuçar a complexidade que gira em torno da problemática da dualidade humana, é importante dizer que é graças aos estudos de Freud e Jung a ideia existente na atualidade sobre a unidade subjetiva do sujeito como decorrente de estruturas psíquicas. Esses estudiosos inscrevem a dualidade no interior do homem, como elemento constitutivo dele.

No conto, Romana experimenta o dilema do homem moderno, a fragmentação que lhe é inerente enquanto ser, aquele que se projeta na imagem da fera, vivenciando, pois, um tipo de narcisismo que o esvazia de si mesmo. Convém ressaltar que é a partir de Tigrela que a mulher aprende o sentido do ato contemplativo diante do espelho, conforme é dito pelo narrador "já não sei se foi com ela que aprendi a me olhar no espelho com olho de fenda" (TELLES, 1981, p. 93). O reflexo parece ativar uma força de atração que permite a reduplicação ou unificação das duas personagens.

A incursão na humanização de Tigrela se inscreve na ordem da transgressão da realidade, pois as atitudes que denotam a experiência civilizada, a sofisticação e o bom gosto do animal acentuam a tensão entre o real e o irreal, a fantasia e a imaginação, o possível e o impossível. A partir dos traços figurativos que definem o perfil de Tigrela verificam-se a animalidade e humanidade num só corpo. Experiências sensoriais e olfativas enaltecem o requinte da domesticação da tigresa, o ser que dança tango, dorme com a dona na mesma cama, adora o "conforto veludoso" dos tapetes persas, gosta de jóias e Bach. A estranheza da civilidade da felina se verifica, ainda, em suas preferências, pois, a personagem adora vestidos de seda; se alimenta somente de legumes, ervas frescas e leite com mel; tem as gengivas muito sensíveis e, por isso, só usa escova de dentes de cerda natural e pasta com sabor de hortelã.

A sensibilidade musical, as atitudes seletas em relação ao que consome e a experiência meticulosa com a seda, o uísque e outros adereços referidos na configuração da ambientação da morada, ao mesmo tempo em que realçam a estranheza da situação, reforçam a ironia que se verifica no discurso do narrador. Para ficarmos apenas com um exemplo, convém lembrar a justificativa dada pela personagem nas atitudes cotidianas de Tigrela: "Não usava o fio dental porque não comia nada de fibroso mas se um dia me comesse, sabia onde encontrar o fio" (TELLES, 1981, p. 97). O fio dental enquanto metáfora traz à tona um detalhe da vida civilizada e um cuidado com a saúde e a higiene pessoal, dados que demarcam fronteiras entre mulher e animal, ao mesmo tempo em que coloca o ato como aspecto transgressor da realidade.

A domesticação de Tigrela, treinada e mimada como humano, é representativa de um rol de situações atípicas que demonstram a integração naturalizada do animal na ação narrativa. Neste cenário incomum e aparentemente impossível, uma metáfora significativa suscita interpretações sobre a verdade dos fatos narrados: o consumo de álcool pelas 
personagens, aspecto referido expressivamente pelo narrador. Ambas apreciam uísque e Tigrela, por sua vez, reconhece a originalidade e qualidade de um bom uísque:

Tigrela sabia quando o uísque era falsificado, até hoje não distingo mas uma noite ela deu uma patada na garrafa que voou longe, por que fez isso, Tigrela? Não respondeu. Fui ver os cascos e então reconheci, era a marca que me deu uma alucinante ressaca. (TELLES, 1981, p. 98)

O álcool remete ao campo dual do ser, pois altera o senso de seriedade. Lembra o culto a Dioniso, o estado de embriaguez que leva a desautomatização do cotidiano, permitindo a transgressão de rígidas regras do comportamento social. $\mathrm{Na}$ ação da personagem, a percepção dos sentidos e a cultura evocam comportamentos que não são da natureza do animal. Mas, a brutalidade inerente a espécie, traz à tona a selvageria que lhe é inata, o que se verifica em atitudes da felina ao ser contrariada, como por exemplo a patada na garrafa, descrita no fragmento apresentado acima. O ciúme é também motivo de sentimento de agressão, o retorno às origens ou à lei da selva, referida textualmente pelo narrador ao caracterizar o jardim como o habitat natural, conforme podemos ver no fragmento que segue:

Finge que não liga mas a pupila se dilata e transborda como tinta preta derramando no olho inteiro, já falei nesse olho? É nele que vejo a emoção, o ciúme. Fica intratável. Recusa a manta, a almofada e vai para o jardim, o apartamento fica no meio de um jardim que mandei plantar especialmente, uma selva em miniatura (TELLES, 1981, p. 98).

Para a lei da selva não há contrato de convivência, assim Tigrela pode agir irracionalmente e voltar a ser o animal enjaulado que é.

Embora humanizada pela dona, Romana tem consciência dos perigos e riscos que corre ao conviver com a felina, conforme podemos perceber nos trechos que seguem:

na depressão se exalta, quase arrasou com o jardim, rasgou meu chambre, quebrou coisas. (TELLES, 1981, p. 94)

$[\ldots]$ quase agredira a empregada anterior, uma jovem. Enquanto essa jovem esteve comigo, Tigrela praticamente não saiu do jardim, enfurnada na folhagem, o olho apertado, as unhas cravadas na terra. (TELLES, 1981, p. 95)

[...] mas é esperta, farejou até sentir cheiro de homem em mim. Ficou uma fera. (TELLES, 1981, p. 98)

[...] encontrei o fio complemente moído, as marcas dos dentes em toda a extensão do plástico. Não disse nada mas senti que me observava por aquelas suas fendas que atravessavam vidro, parede. (TELLES, 1981, p. 99)

A porta do terraço está aberta, também ficou aberta outras noites e não aconteceu mas nunca se sabe, é tão imprevisível, acrescentou com voz sumida. [...] Volto tremendo para o apartamento porque nunca sei se o porteiro vem ou não me avisar que de algum terraço se atirou uma jovem nua, com um colar de âmbar enrolado no pescoço. (TELLES, 1981, p. 99) 
Na cena final do conto - a possível "fuga" do animal do cativeiro em que viveu, no suposto jardim "zoológico" partilhado pela parceira Romana - o que resplandece é a reconciliação da poesia com o mito, a ambiguidade inerente ao relato fantástico, pois, com este fim enigmático, o leitor finaliza a leitura com uma série de questionamentos sem respostas.

Sobre a ambiguidade e ambivalência dos fatos narrados, convém ressaltar, ainda,a ação da personagem Romana ou o modo de configuração da animalização da mulher. No desenho fabular, traços de uma suposta solidão realçam irracionalidade e atitudes embrutecidas ligadas por um fio comum: o vazio da separação, sentimento natural de quem experimentou o drama da perda amorosa ou de quem "se separou do quinto marido" (TELLES, 1981, p. 93). Logo no início da trama, Romana é apresentada como quem "[e]stava meio bêbada" (TELLES, 1981, p. 93), medrosa e carente, pois afirma por duas vezes a amiga: "eu preciso de você" (TELLES, 1981, p. 93). A própria personagem tem consciência da estranheza de si e da situação atípica que se tornou na convivência com a felina, o que ela classifica como loucura e jogo: "já sei, você está me achando louca mas assim de fora ninguém entende, é complicado. E tão simples, você teria que entrar no jogo para entender (TELLES, 1981, p. 96).

O gesto de trincar o gelo nos dentes, referido duas vezes pelo narrador, sugere também um ato de selvageria da personagem. Acrescente-se a isso a atitude de Romana de afundar a cenoura no sal e lamber o alimento. Outro fator que sugere animalização é no uso da linguagem, pois, em alguns momentos a mulher acelera a emissão da palavra a ponto de não ser compreendida pela amiga. "Romana falava tão rapidamente que tive de interrompê-la, mais devagar, não estou entendendo nada! Freou as palavras mas logo recomeçou o galope desatinado, como se não lhe restasse muito tempo" (TELLES, 1981, p. 98).

$\mathrm{Na}$ trama a condição de vestir-se ou de estar nua parece demarcar fronteiras entre a humanização e a animalização da mulher. Na narrativa, há um momento em que a mulher veste o casaco - "Vesti o casaco, mas tinha esfriado? (TELLES, 1981, p. 96). O casaco que é um signo de proteção "artificial" contra o frio, sugere a condição nata de ser humano. Mas, no final da história narrada, o narrador refere-se a possibilidade de uma jovem nua atirar-se pela janela. Pelo modo como tal gesto é referido, um ato decorrente de um possível desvario, o leitor não é capaz de discernir quem seria o sujeito da ação, pois tanto pode ser Tigrela como pode ser Romana .

A ambiguidade da narrativa instiga questionamentos variados e sugestões diversas sobre o relato. Vera Maria Tietzmann Silva (2001, p. 67), por sua vez, ao referir-se às incertezas do conto destaca que nesta narrativa parece ocorrer um processo de metamorfose ou mesmo uma relação amorosa entre as duas personagens. Assim referese a autora sobre a narrativa:

“Tigrela" é uma história recontada, o que inclui a dúvida adicional sobre a confiabilidade dos dois narradores sucessivos. Além de leitor e narrador ficarem hesitantes quanto à ocorrência ou não da metamorfose, insinua-se ainda a possibilidade de tudo não passar de uma metaforização. Quer dizer, Tigrela bem pode ser de fato uma moça que mantém uma relação 
lésbica com Romana, a primeira narradora, dissimulada na narrativa, sob a capa de uma metáfora.

No trânsito entre a estreita condição de ser mulher e ou bicho e vice versa se verifica a passagem de limites e de fronteiras de realidades antagônicas, o que permite o conflito entre o possível e o impossível.

No interior da diegese lygiana, a referência à meia noite é um emblema da dualidade, pois sugere um entrecruzamento de mundos diametralmente opostos, trazendo à tona a confluência de realidades aparentemente contrárias. "Quando soube que faltava pouco para a meia noite baixou o olhar num cálculo sombrio. Ficou em silêncio (TELLES, 1981, p. 94).

Sobre a noite como procedimento formal e temático na literatura fantástica, Ceserani destaca: "A ambientação preferida pelo fantástico é aquela que remete ao mundo noturno” (2006, p. 77). A meia noite no imaginário coletivo é representativo da magia e do mistério, horário de encantamento ou desencantamento, signo da incompreensível cisão/fusão de contrários. É o turno propício para provocar nos seres ficcionais sentimentos de medo e de terror e criar condições necessárias para que aflore a atmosfera fantástica ou uma mudança de percepção que possa colocar em cena o efeito de estranhamento como mecanismo de irrealidade, traço fundamental para colocar em choque o real e o inexplicável ou para suscitar reflexões sobre a verdade e a imaginação, onde reside o sentimento do fantástico. Conforme ressalta Roas (2014, p. 135), é a partir da transgressão que nasce o estranhamento, diz respeito àquilo "que deixa de ser familiar e se converte em algo incompreensível e, como tal, ameaçador. (ROAS, 2014, p. 135).

É assim entre variadas instâncias duais - humano e inumano, razão e loucura, realidade e fantasia, o crível e o não crível, o inexplicável e o perturbador - em que é erguido o drama de Romana e onde o fantástico é acolhido. $\mathrm{Na}$ ação da personagem, os limites e as fronteiras entre tais realidades são tênues, pois constitui tarefa árdua ao leitor tentar estabelecer demarcações precisas que separem tais instâncias, o que nos faz lembrar a perspectiva oportuna de Ceserani $(2006$, p. 73$)$ sobre tal procedimento na configuração do relato fantástico, onde ocorre, "a passagem da dimensão do cotidiano, do familiar e do costumeiro para a do inexplicável e do perturbador: passagem de limite, por exemplo, da dimensão da realidade para a do sonho, do pesadelo, ou da loucura".

\section{REFERÊNCIAS}

BAUMAN, Zygmunt. Amor líquido: sobre a fragilidade dos laços humanos. Rio de Janeiro: ZAHAR, 2004.

BRAVO, Nicole F. O duplo. In: BRUNEL, Pierre. Dicionário de mitos literários.2. ed. Rio de Janeiro: José Olympio, 1997. p. 261-288.

CADERNOS DE LITERATURA BRASILEIRA: Lygia Fagundes Telles. São Paulo: Instituto Moreira Sales, 2002. 
CALVINO, Ítalo. Contos fantásticos do século XIX: o fantástico visionário e o fantástico cotidiano. São Paulo: Companhia das Letras, 2011.

CESERANI, Remo. O fantástico. Curitiba: Editora UFPR, 2006.

DERRIDA, Jacques. O animal que logo sou. Tradução Fábio Landa. - São Paulo: Editora UNESP, 2002.

FINNÉ, Jean. La littérature fantastique. Essai sur l'organisation surnaturelle. Bruxelles: Éditions de l'Université de Bruxelles, 1980.

FURTADO, Felipe. A construção do fantástico na narrativa. Lisboa: Livros Horizonte, 1980.

GIDDENS, Anthony. As conseqüências da modernidade. Tradução de Raul Fiker. São Paulo: Editora UNESP, 1991.

HEIDEGGER. Os pensadores. Trad. e notas:Ernildo Stein. São Paulo: Nova cultural, 1991.

KRISTEVA Julia. História de amor. Trad.Leda Tenório da Motta. Rio de Janeiro: Paz e Terra, 1988.

LAMAS, Berenice Sicas. O duplo em Lygia Fagundes Telles: um estudo em Literatura e psicologia. Porto Alegre: EDIPUCRS, 2004.

LUCAS, Fabio. O conto no Brasil moderno. In: LIMA, Luis Costa. et. al. O livro do seminário. São Paulo: Nestlé /L. R. Editores, 1983, p. 103-161.

MAGALHÃES JÚNIOR, Raimundo. O conto fantástico. In: $A$ arte do conto: sua história, seus gêneros, sua técnica, seus mestres. Rio de Janeiro: Bloch, 1972.

MELLO, Ana Maria Lisboa de. As faces do duplo na literatura. In: INDURSKY, Freda. Discurso, memória, identidade. Porto Alegre: Sagra Luzzatto, 2000.

RIBEIRO, Juliana Seixas. Mistérios de Lygia Fagundes Telles: uma leitura sob a óptica do fantástico. (Dissertação de Mestrado). Campinas, SP: UNICAMP, 2008. Disponível em: < http://libdigi.unicamp.br/document/?code=vtls000439373>. Acesso em: 15 jul. 2008.

ROAS, David. La amenaza de lo fantástico. In: ROAS, David. et. al. Teorías de lo fantástico. Madrid: Arco Libros, 2001. p. 07-44.

Tras los limites de lo real: uma definição de lo fantástico. Madrid: Páginas de Espuma, S. L., 2011. 
- A ameaşa do fantástico: aproximações teóricas. São Paulo: Editora da UNESP, 2014.

RODRIGUES, Selma Calasans. O fantástico. São Paulo: Ática, 1988.

ROSSET, Clemente. O real e seu duplo: ensaio sobre a ilusão. 2. Ed. Rio de Janeiro: José Olympio, 2008.

SILVA, Vera Maria Tietzmann. A metamorfose nos contos de Lygia Fagundes Telles. 2. ed. Goiania: Editora da UFG, 2001.

TELLES, Lygia Fagundes. Mistérios. Rio de Janeiro: Nova Fronteira, 1981.

Recebido em: 28/03/2017 Aprovado em: 25/05/2017 Publicado em: 01/06/2017 